\title{
Effect of modified atmosphere packaging on storage life and quality of cherry tomato under ambient conditions
}

\author{
- Rohit NARAng, S.R. Sharma, T.C. MitTAL And ANKIT KuMAR* \\ Department of Processing and Food Engineering, Punjab Agricultural University, LUDHIANA (PUNJAB) INDIA (Email : \\ jggankit@gmail.com) \\ *Author for Correspondence \\ Research chronicle : Received : 05.04.2017; Revised : 10.05.2017; Accepted : 23.05.2017
}

\begin{abstract}
SUMMARY :
Freshly harvest tomato after washing with water packaged in LDPE packages of various thicknesses $v i z ., 25,37.5$ and $50 \mu \mathrm{m}$ and 0,4 and 8 perforations of $1.0 \mathrm{~mm}$ diameter each and a separate sample was taken for comparison under ambient storage conditions $\left(31.2 \pm 2^{\circ} \mathrm{C}\right.$ and $\left.74.5 \pm 3 \% \mathrm{RH}\right)$ with a view to improve the storage life and quality. Packaged fruit were assessed for Gas concentrations $\left(\mathrm{O}_{2}\right.$ and $\mathrm{CO}_{2}$ ) and quality parameters such as PLW, colour, firmness, lycopene content, TSS, titrable acidity and sensory evaluation. Results obtained were analyzed statistically with the help of ANOVA and DMRT $(\alpha=0.05)$. Higher $\mathrm{O}_{2}$ concentration $(16.10 \%)$, lower $\mathrm{CO}_{2}$ evolute $(7.41 \%)$ was observed in 37.5 $\mu \mathrm{m}$ packaging with 8 perforations. Lower PLW was observed to be 3.78 per cent and 3.97 per cent of initial weight in non-perforated $25 \mu \mathrm{m}$ and $37.5 \mu \mathrm{m}$, respectively. TCD was observed to lowest (8.10) and firmess better retained by $37.5 \mu \mathrm{m}$ with 8 perforation. Among all the treatments, $37.5 \mu \mathrm{m}$ LDPE packages with 8 perforations were found to be the best package and cherry tomato could be stored for upto 12 days ambient storage conditions.
\end{abstract}

KEY WORDS : Cherry tomato, Modified atmosphere packaging, Total colour difference (TCD), Physiological loss weight (PLW), Sensory evaluation

How to cite this paper : Narang, Rohit, Sharma, S.R., Mittal T. C. and Kumar, Ankit (2017). Effect of modified atmosphere packaging on storage life and quality of cherry tomato under ambient conditions. Internat. J. Proc. \& Post Harvest Technol., 8 (1) : 29-36. DOI: 10.15740/HAS/IJPPHT/8.1/29-36.

$\mathrm{F}$ Truits and vegetables form an essential component of the nourishment in India, where the principal population is vegetarian and thus vegetable cultivation is a remarkable section of the agricultural economy (Chandrasekharam, 2012). Tomato (Lycopersicon esculentum, Mill) is one of the most widely consumed vegetables in the world. The production of tomato in India is $18,736,000$ million tonnes and the area under cultivation is 882,000 hectare (Anonymous,
2015). Organic products like tomato, post harvest taking care of is as basic as creation practices because of their delicate nature. Post harvest losses may occur at any stage in the handling system from harvesting through storage and marketing to final delivery to the consumer. Due to its climacteric nature, tomato is highly perishable especially in tropical and subtropical areas. Nearly 30-50 per cent of the produce is lost after harvest because of inadequate handling and preservation (Inaba and Crandall, 